\title{
REVIJA ZA GEOGRAFIJO - nova slovenska geografska revija Oddelka za geografijo Filozofske fakultete v Mariboru
}

Koncem lanskega leta je Oddelek za geografijo, na leta 2006 ustanovljeni Filozofski fakulteti Univerze v Mariboru, z izdajo prvih dveh številki prvega letnika (2006) nove geografske revije prijetno presenetil slovensko geografsko, nedvomno pa tudi širšo strokovno javnost in seveda $\mathrm{v}$ celoti tudi okolje, ki mu bo $\mathrm{v}$ bodoče nedvomno posvečeno več pozornosti v slovenski geografski literaturi. Kot je v uvodu zapisal njen urednik Igor Žiberna, želijo tudi na mariborskem Oddelku »slediti poslanstvu stroke, kar ni več le skrb za raziskovanje in izobraževanje, pač pa tudi objavljanje rezultatov svojega dela«. Oddelek je že doslej dokaj pogosto izdajal posebne, vsebinsko zaokrožene zbornike, še več pa je objavljal v tujih geografskih revijah. »Revija za geografijo« pa mu je odprla nove možnosti tovrstne afirmacije in tudi aplikacije svojega, že kar obsežnega opusa znanstveno - raziskovalnega dela in mednarodnega sodelovanja.

Morda ni odveč spomniti na izredno zanimivo in sistematično razvojno pot danes tako na znanstveno - raziskovalnem, kot na pedagoškem področju uveljavljenega Oddelka, ki jo je sedaj nadgradil še z lastno znanstveno revijo. Od zgodovinsko - geografskega oddelka na Pedagoški akademiji pred okrog petdesetimi leti je zrasel samostojni geografski oddelek na Pedagoški fakulteti, ki je v osemdesetih letih s krajšim ali daljšim sodelovanjem kar sedmih predavateljev s Filozofske fakultete v Ljubljani premostil generacijsko menjavo učiteljev ob hkratnem širjenju svojega pedagoškega programa, do prehoda na podiplomski študij in lani na mariborsko Filozofsko fakulteto. Lastna znanstvena revija ob obsežnem in razvejanem znanstveno raziskovalnem delu je bila tako le še vprašanje časa.

Nekako logično je prva številka Revije za geografijo prvenstveno namenjena geografski problematiki Maribora, ki je bila v širšem vsebinskem obsegu leta 2006 predstavljena tudi v 250 številki geografske revije Katedre za gospodarsko geografijo in regionalno planiranje iz Bayreutha, Arbeitsmaterialien zur Raumordnung und Raumplanung (št. 250). Neumorni raziskovalec in odlični poznavalec geografske in tudi širše sorodne problematike mesta ter so snovalec najnovejšega urbanističnega plana razvoja Maribora V. Drozg podaja v kar 30 strani dolgi študiji svoja razmišljanja o Mariboru kot regijskem mestu na konkretnih teoretskih in metodoloških zasnovah urbano - suburbanih odnosov. V vrsti najnovejših študij suburbanizacijske problematike pri nas, je to tako na kompleksnem kot na aplikativnem področju nedvomno tehten korak naprej.

Da se Maribor že dolga leta sooča s problemom depopulacije, ob tem pa tudi socialne degradacije in, kot avtor navaja celo »getoizacije« posameznih delov mesta, opozarja U. Horvat v študiji o razvoju mariborskega prebivalstva med letoma 1981 in 2002 . Zdi se, da je tovrstna problematika, povezana s suburbanizacijskimi procesi, ob bolj ali manj »turbokapitalističnem« stihijskem razvoju ne le naših mest, mnogo bolj pereča, kot se o tem razmišlja in upošteva pri konkretnem načrtovanju in spremljanju razvoja mest. Ali nimamo že v neposredni soseščini (Rim) procese, ki spominjajo na razvoj, ki so ga mesta razvitih evropskih držav doživljala ob višku ekonomskih migracij v šestdesetih in sedemdesetih letih prejšnjega stoletja in ki ga doživljajo velika mesta $v$ manj razvitih območjih sveta. 
Soodvisnost demografskega in gospodarskega razvoja Maribora je očitna iz naslednjega prispevka L. Lorber o strukturnih spremembah mariborskega gospodarstva po letu 1991. Na prikazu izbranih relevantnih statističnih podatkov zasnovana študija navaja v zaključku vzroke za krizo mariborskega gospodarstva ter splošne smernice za izboljšanje stanja.

V naslednjem prispevku I. Žiberne primerja spremembe temperature zraka med meteorološkima postajama Starše na Dravskem polju in Maribor v obdobju 1961 - 2004, ko se zaradi človekovega vpliva, predvsem pa širjenja pozidanih površin, poglablja mestni toplotni otok in krepi njegov vpliv na izbrane bioklimatske kazalce. Nič manj ni zanimiv prispevek A. Vovk Korže o zelenih površinah kot dejavniku kvalitete okolja v Mariboru.. Zanimivo pri tem je, da prikazane vsebine večinoma dopolnjujejo v dosedanjih geografskih študijah obravnavano geografsko problematiko Maribora, pri čemer mislim predvsem na knjigo »Maribor/Marburg, prispevki h geografiji prijateljskih mest« (1994) in številne študije mestnih elementov v zadnjih letih. Po vsem tem bi si Maribor kmalu zaslužil tudi vsebinsko čim bolj popolno geografsko monografijo.

Prvo številko Revije za geografijo zaključujeta zanimiva informativna prispevka o študiju geografije v Mariboru avtorice K. Kolenc Kolnik in o nekaterih značilnostih osnovnošolskega in srednješolskega izobraževanja v Mariboru. Avtorice E. Konečnik Kotnik.

Druga številka Revije za geografijo prinaša prispevke geografov z Univerz v Bayreuthu, Bratislavi, Gradcu, Mariboru, Pecsi in Plznu, združenih v neformalno skupino »Raziskovalni šesterokotnik«. Redna oblika sodelovanja geografskih oddelkov z navedenih Univerz, pri katerem je pred leti še v ožjem okviru sodeloval tudi Oddelke za geografijo z ljubljanske Filozofske fakultete, so vsakoletni simpoziji v različnih središčih in objavljeni zborniki referatov.

Vsebinskotežiščedrugegazvezka Revijezageografijojenaobravnavirazvojnihprocesov in problemov urbanih območij in prostorskega planiranja. Oba, teoretsko in metodološko ustrezno podprta aspekta, sta morda najbolj temeljito prisotna v razpravah J. Maierja, B. Kadner in M. Gutgesella o perspektivah razvoja mesta Rehau na Gornjem Bavarskem, W. Zsilincsarja o medobčinskem gospodarskega in regionalno razvojnem sodelovanju na primeru zgostitvenega območja Voitsberg na zahodnem Štajerskem ter M. Floriana, A. Tropperja in W. Zsilincsarja o podobni problematiki v aglomeraciji obmejne Lipnice. Ker gre za razvojne probleme, s slovenskimi primeri primerljivih, »aglomeracij« malih mest, so navedeni geografski prispevki vsekakor tudi koristni pri podobnih proučevanjih in tudi pri konkretnih ravnanjih pri nas. S podobno regionalno razvojno problematiko se ukvarjajo prispevki obeh čeških in madžarskega avtorja; A. Matouškova piše o razvoju demografskih in urbanih struktur v urbani regiji Pilzna, J. Dokoupil o gospodarskem razvoju in o razvoju mestne regije Pilzna, T. Csapo pa o funkcijski strukturi madžarskih srednje velikih in velikih mest s konkretnimi primeri Szegeda, Karcaga, Kazincbarcika, Debrecena in Dunaujvarosa. Širšo regionalno razvojno problematiko pa prinašajo prispevki J. Ježeka o pomenu prostovoljnega povezovanju občin kot dejavniku trajnostnega razvoja podeželskih območij na Češkem, A. Auberta o pomenu rekreacije v urbanizacijskem procesu na Madžarskem in M. Berki o možnostih izkoriščanja turističnega potenciala manj razvitih območij v južnem Podonavju. 
Dva prispevka slovenskih avtorjev obravnavata Maribor in njegovo urbano regijo kot problemski prostor. Tako je razprava L. Lorber pri nas ena redkih, za prostorski, socialni, funkcijski in seveda $s$ tem povezani sonaravani razvoj industrijske zone na Teznem in Maribora v celoti, izredno pomembnih in to ne le geografskih, študij na sploh. V prispevku »Mestna regija Maribora« V. Drozg razmišlja predvsem o njenem obsegu in njenem regionalno razvojnem. S. Pelc pa na osnovi demografskih podatkov razmišlja z vidika gospodarskih značilnosti o novih dimenzijah geografske narginalnosti v okviru središčno obrobnega razvojnega modela.

Strokovna tehtnost, aktualnost, meddisciplinska in mednarodna usmeritev vsebin nove geografske revije »Revija za geografijo« vsekakor napoveduje njen tehten prispevek stroki, regiji in h kvalitetnejšemu, kompleksnejšemu ter sonaravno naravnanemu reševanju prostorske in v širšem regionalno razvojne problematike. »Revije za geografijo« smo geografi nedvomno veseli in ji želimo dolgo »življenje«.

Dr. Mirko Pak 